\title{
Some Characteristics of Successful Alumni
}

\begin{abstract}
Study was made of selected characteristics of fifty-two successful and fifty unsuccessful alumni of the Drexel library school. The average successful alumnus had been younger and healthier while in library school, had been both graded and evaluated higher by his instructors, had come from a more prestigious undergraduate institution, had probably done more graduate work and held more library positions before attending library school, than the average unsuccessful alumnus. His undergraduate major field appears to have had no particular relevance to his success.
\end{abstract}

$\mathrm{T}$ HE STUDY reported here was undertaken in an effort to determine the relationship between the career success of certain outstanding graduates of the graduate school of library science, Drexel Institute of Technology, and certain variables related to their attendance at Drexel. It was hoped that such a study might help in formulating improvements in admission policies.

\section{METHOD}

Two lists were used: the first comprised the names of fifty-two graduates whose employment records suggested that they had been unusually successful in their positions; the other named fifty graduates and former students whose records showed them to have been unsuccessful either as Drexel students or in their library positions. Both lists were constructed on the basis of faculty evaluations, employment records, and pro-

Miss Parr is Assistant Professor of Library Science in Pratt Institute, and Miss Filderman is Administrative Assistant in the Graduate School of Library Science at Drexel Institute of Technology. fessional recognition, and the names included were drawn from a thirty-year period. In choosing the successful and unsuccessful groups, each of several faculty members and the placement director were asked to submit the names of alumni who were nationally respected in specific fields, and others who appeared to be equally unsuccessful, were problem cases, or "lemons." The successful group included heads of leading libraries and library systems and alumni who had served as officers in national library associations. The unsuccessful group included former students and alumni who were very difficult to place, or who had flunked out of library school yet held on to an inferior job, or who had never advanced beyond a $\$ 4,000$ job.

The following were analyzed in connection with each of the successful and unsuccessful graduates and former students: (1) age while in library school, (2) health, (3) faculty evaluations at Drexel, (4) scholastic standing at Drexel, (5) undergraduate colleges, (6) graduate degrees, (7) undergraduate majors, (8) pre-Drexel and pre-job li- 
brary experience, and (9) college language training.

Information relative to all of these points was compiled from the folders of the 102 students. In the paragraphs that follow under Findings these data are presented for two groups: Group S, graduates judged successful, and Group $\mathrm{U}$, those considered unsuccessful.

\section{Findings-Group S}

Age while in library school. At the time of their period of study at Drexel the average age was twenty-seven. A large portion of this group had enrolled in library school shortly after college graduation.

Health. Only three members of this group (6 per cent) had records of poor health.

Drexel faculty ratings. As is probably to be expected, the faculty ratings received by the individuals were favorable almost without exception. Phrases such as "superior ability," "seriousness of purpose," "personable," and "professional ability" were commonly used.

Scholastic standing at Drexel. An analysis of the forty scholastic averages which were available revealed that twenty-six (65 per cent) ranked in the top third of their Drexel graduating classes, and that eleven ( 27 per cent) were among the first five persons of their classes.

Undergraduate education. If institutions attended for baccalaureate degree can be categorized as being "prestige" (the better known colleges and universities of large or selective enrollment) and "non-prestige" (teachers', nonaccredited, small, unselective, or vocational colleges), 64 per cent of the persons in Group $\mathrm{S}$ received their undergraduate education at "prestige" colleges and universities. Also, six of this group (15 per cent) had been graduated magna cum laude by their undergraduate colleges. Graduate degrees. Seven (14 per cent) held graduate degrees at the time of admission to the library school. All were master's degrees; none held doctorates. Of these, three had earned the master's degree in education, one each in French, literature, classical languages, and food technology.

Undergraduate majors. The majority of the group indicated that their field of concentration had been the liberal arts, many of them having been English majors.

Pre-Drexel and pre-job library experience. There seems to have been a definite relationship between library experience before graduation and success following graduation. More than twice as many persons in Group S as in Group $\mathrm{U}$ were employed in libraries before graduation. Many of the positions these individuals held were listed as "professional" and involved considerable responsibility; many were in such positions before entering library school.

College language training. More than half had studied two foreign languages, and all of them at least one; 12 per cent had studied four languages.

\section{Findings-Group U}

Age while in library school. The average age of this group was thirty-four which suggests that more individuals had spent time in other occupations than had those in Group S.

Health. Eleven of the fifty persons in Group U (22 per cent) were victims of serious illness or had physical defects, often causing frequent class absence.

Drexel faculty evaluations. Many were characterized by their instructors as "egocentric," (10 per cent); "immature," (22 per cent); "not alert" or "slow to learn," (30 per cent); and "untidy," "poor appearance," or "unpoised" (12 per cent).

Scholastic standing at Drexel. Grade point averages were found for all fifty members of Group U. Of these, thirty- 
on conventional scientific publishing. John Markus of McGraw-Hill offered in some detail a photocopying royalty plan that might prove an equitable solution to the problems of copyright and photocopying.

One cannot judge the substance and worth of a conference by its printed proceedings, and the participants in the conclave may have gained considerable insight into the implications of the Warren proposal for library planning. If so, such insights have eluded the editor. Competent university librarians evidently found their assignment of relating the Warren proposal to library planning a bit sticky for they frequently retreated to discussing tangential matters such as the quality of microfilm readers and local applications of computers to library operations. The Osborne paper on automation and library design was too general to generate dialogue among the panelists.

To stir librarians, Dr. Warren circulated his memorandum in a "white paper" to

\section{ALUMNI . . . \\ (Continued from page 226)}

one (62 per cent) were in the lower third of their Drexel graduating classes, and seven (14 per cent) were among the bottom five individuals graduating that year.

Undergraduate education. Only 36 per cent (half as many as of Group S) attended institutions in the "prestige" group.

Graduate degrees. There was one individual in Group $U$ with an advanced degree ( 2 per cent).

Undergraduate majors. Group $\mathrm{U}$ as Group S showed their major fields of concentration to be in the liberal arts area, many of them English majors.

Pre-Drexel and pre-job library experience. Of the persons making up Group $\mathrm{U}, 30$ per cent had never worked in a library, and 33 per cent had been employed in such capacities as student assistants, typists, or menders of books.

College language training. In Group $\mathrm{U} 10$ per cent had no foreign language training whatsoever; however, 12 per members of the Association of Research Libraries. The official comment of the Association (Appendix G, Minutes of the SixtyFifth Meeting, January 24, 1965, Washington, D.C.) stated that the Association concurred in the objectives but that there were proposals and assumptions in the report that seemed impractical, unnecessarily cost$l y$, and inefficient. The statement in these minutes should be measured against the general and somewhat superficial reactions of the conference which failed to produce a sophisticated and critical analysis of the proposal and its relationships to comparable plans for information control. The bits and pieces offered on various facets of automation and library planning contribute little or nothing to that subject. Entitling these proceedings Library Planning for Automation seriously misleads librarians who seek aid in planning for the new technology.-Robert T. Grazier, Wayne State University.

cent had studied four or more languages. Conclusions

This limited sampling seems to indicate that there were several evident characteristics of the successful graduate of the Drexel library school: (1) these graduates were somewhat younger than their less successful fellows, many having enrolled shortly after completion of an undergraduate degree; (2) they enjoyed better general health; (3) the Drexel faculty evaluations of them during their days as graduate students quite consistently forecast professional success; (4) their scholastic success was a good indicator of their future professional success; (5) the quality of their undergraduate college often indicated the quality of the individual; (6) they were somewhat better prepared by having undertaken graduate work in other areas as well; (7) a high per cent of this group had previous library job experience, many bearing considerable responsibility; (8) this group showed somewhat stronger language background. Perhaps it should be pointed out that only one 